\title{
COVID-19 in children: reasons for uneventful clinical course
}

Sweni Shah, MD, MRCP ${ }^{1}$, Ramachandran Meenakshisundaram, MBBS, MRCP, PhD, PGCert in HBE, FHEA ${ }^{2}$, Subramanian Senthilkumaran, $\mathrm{MD}, \mathrm{PhD}^{2}$, Ponniah Thirumalaikolundusubramanian, $\mathrm{MD}^{3}$

${ }^{1}$ Royal Free NHS Foundation Trust, London, United Kingdom; ${ }^{2}$ Department of Emergency \& Critical Care, Manian Medical Centre, Erode, India; ${ }^{3}$ Trichy SRM Medical College Hospital and Research Centre, Irungalur, Tiruchirapalli, India

\section{Key message}

Coronavirus disease 2019 (COVID-19) infection is reported among neonates and children; however, this population has far fewer secondary complications than adults. This could be due to the high angiotensin-converting enzyme 2 expression, primed immune system, and reduced cytokine storm in children. In addition, recurrent viral infections in young children may offer some protection against COVID-19 via cross-reactive immune status, microbial interactions, and competition.

Severe acute respiratory syndrome coronavirus 2 (SARSCoV-2) causes coronavirus disease 2019 (COVID-19), currently a pandemic. The cause of this disease has been found, but the mechanism of pneumonia and other symptoms, as well as the reasons for milder symptoms in children remain unknown. The explanations are based on current hypotheses from clinical, epidemiological, physiological, and immunological concepts.

Epidemiologically, reporting and testing of children for COVID-19 are less frequent, which leads to the problem of undersampling and underreporting. Decreased illness severity and an overall disease resilience in children facilitates its transmission by rendering children as carriers. ${ }^{1)}$ Despite evidence that angiotensin-converting enzyme (ACE) 2 is implicated in the pathology of COVID-19 lung injury, increased ACE2 expression or immature ACE2 structure in pediatric lungs and other tissues may protect the lungs and other organs from an adverse clinical course and complications. ACE2 expression in the intestines of children explains why children may have a longer viral shedding period than adults. ${ }^{1)}$

The immune system of children is more active than that of adults and exerts protective action in the early phase of SARS$\mathrm{CoV}-2$ infection by controlling viral replication. ${ }^{2)}$ Moreover, vaccinations and frequent viral infections in children enhance immune system activation ${ }^{3)}$ and may contribute to the uneventful clinical course seen in most cases. Coronavirus infections in pediatric and young adult population have occurred mainly during winter in some countries. Older children and adults have experienced previous infections, and hence new cases of infection are rare. So, there are opportunities for developing herd immunity to coronaviruses. The rarity of severe symptoms in children with COVID-19 may be attributable to the crossreactive immune status caused by infections at a young age that persists in pediatric and young adult groups compared to the elderly. Hence, we hypothesize that microbial interaction and competition may reduce COVID-19 illness severity in children.

Innate immune cells have the capacity to recognize pathogenassociated molecular patterns and initiate a pro-inflammatory and interferons (IFNs) cascade. IFNs increase cytotoxic T and natural killer (NK) cell activities. NK cells move to infected sites and produce IFN-gamma, which is involved in killing the virus-infected cells and boosting the adaptive immune response. Furthermore, interferons activate Janus kinase signaling pathway and lead to the upregulation of interferon-controlled genes that kill the viruses. ${ }^{4)}$

The adaptive immune response through $\mathrm{T}$ helper cells also plays a crucial role in the severity of COVID-19. The relatively immature adaptive immune system in children may be a cause of mild clinical symptoms; however, this remains to be clarified. Interestingly, other infectious diseases (hepatitis A, mycoplasma pneumonia) and immunological diseases (Kawasaki disease, acute post-streptococcal glomerulonephritis, Henoch-Schonlein purpura) also have milder clinical symptoms in younger children than older children or adults. ${ }^{5)}$ Chen et al. ${ }^{2)}$ demonstrated that CD4 helper T cells stimulate B lymphocytes to create an antibody response against SARS-CoV-2 in mice. Thus, the cellular immune system responses (CD4 $+\mathrm{T}$ cells) to SARS-CoV-2 infection in senescent BALB/c mice are important in the control of infection. ${ }^{2,6)}$ The higher production and efficiency of $\mathrm{T}$ helper cells in children may offer additional protection against COVID-19.

The causative agent of COVID-19 may not be SARS-CoV-2 alone; it may also be the substances excreted by cells infected with the virus or other pathogens of the human microbiota ${ }^{7}$ as seen in cases of Kawasaki disease ${ }^{5)}$ and many others.

Physiologically, a higher total lymphocyte count in children could offer greater immune protection against COVID-19. Additionally, children have a beating lung cilia of higher frequency, ${ }^{8)}$ which may hinder the virus's entry into lung pneumocytes.

Corresponding author: Sweni Shah, MD, MRCP. Royal Free NHS Foundation Trust, Pond Street, London, NW3 2QG, United Kingdom 凶E-mail: sweni.shah@nhs.net, https://orcid.org/0000-0001-9761-7047

Received: 1 May, 2020, Revised: 26 May, 2020, Accepted: 3 June, 2020

This is an open-access article distributed under the terms of the Creative Commons Attribution Non-Commercial License (http://creativecommons.org/licenses/bync/4.0/) which permits unrestricted non-commercial use, distribution, and reproduction in any medium, provided the original work is properly cited.

Copyright (c) 2020 by The Korean Pediatric Society 
Lack of comorbidities as well as less exposure to environmental pollutants and toxins in children are the other physiological factors contributing toward protection of the lungs and airways. Furthermore, a satisfactory nutritional status and relative lack of physical and mental stress in children likely contribute to protection.

Acute respiratory distress syndrome (ARDS) in COVID-19 is initiated by the deposition of fibrin in the airspaces and lung parenchyma along with fibrin-platelet microthrombi in the pulmonary vasculature and progressive respiratory dysfunction. 9) Children are at lower risk for COVID-19-associated ARDS since they have lower thrombin generation potential and decreased fibrin formation velocity. ${ }^{10)}$ Lung injury and multiorgan failure in COVID-19 are also due to cytokine storm, an inflammatory response ${ }^{11)}$ which the immune system of children is less capable of mounting.

In conclusion, children have high expression of ACE2, a sensitized immune system, decreased frequency of cytokine storm, and healthy physiology, which explain the lower COVID-19 complication rate. The prevalent SARS-CoV-2 virus has caused a few fatalities in neonates and infants and from transplacental infections. Therefore, it can be considered a kind of microbiota adapted to the human species with inherently low virulence. Underreporting of cases, subclinical syndrome, and longer viral shedding period in children contribute to a hidden link in viral transmission.

\section{Conflicts of interest}

No potential conflict of interest relevant to this article was reported.

\section{References}

1. Ma X, Su L, Zhang Y, Zhang X, Gai Z, Zhang Z. Do children need a longer time to shed SARS-CoV-2 in stool than adults? J Microbiol Immunol Infect 2020;53:373-6.

2. Chen J, Lau YF, Lamirande EW, Paddock CD, Bartlett JH, Zaki SR, et al. Cellular immune responses to severe acute respiratory syndrome coronavirus (SARS-CoV) infection in senescent BALB/c mice: CD4+ T cells are important in control of SARS-CoV infection. J Virol 2010; 84:1289-301.

3. Benn CS, Netea MG, Selin LK, Aaby P. A small jab - a big effect: nonspecific immunomodulation by vaccines. Trends Immunol 2013;34:431-9.

4. Favalli EG, Biggioggero M, Maioli G, Caporali R. Baricitinib for COVID-19: a suitable treatment? Lancet Infect Dis 2020 Apr 3:S14733099(20)30262-0. https://doi.org/10.1016/S1473-3099(20)30262-0.

5. Rhim JW, Kang HM, Han JW, Lee KY. A presumed etiology of Kawasaki disease based on epidemiological comparison with infectious or immunemediated diseases. Front Pediatr 2019;7:202. https://doi.org/10.3389/ fped.2019.00202.

6. Zhao J, Zhao J, Perlman S. T cell responses are required for protection from clinical disease and for virus clearance in severe acute respiratory syndrome coronavirus-infected mice. J Virol 2010;84:9318-25.

7. Lin L, Zhang J. Role of intestinal microbiota and metabolites on gut homeostasis and human diseases. BMC Immunol 2017;18:2. https://doi. org/10.1186/s12865-016-0187-3.

8. Chilvers MA, Rutman A, O'Callaghan C. Functional analysis of cilia and ciliated epithelial ultrastructure in healthy children and young adults. Thorax 2003;58:333-8.

9. Moore HB, Barrett CD, Moore EE, McIntyre RC, Moore PK, Talmor DS, et al. Is there a role for tissue plasminogen activator as a novel treatment for refractory COVID-19 associated acute respiratory distress syndrome? J Trauma Acute Care Surg 2020;88:713-4.

10. Ignjatovic V, Pelkmans L, Kelchtermans H, Al Dieri R, Hemker C, Kremers R, et al. Differences in the mechanism of blood clot formation and nanostructure in infants and children compared with adults. Thromb Res 2015;136:1303-9.

11. Ng PC, Lam CW, Li AM, Wong CK, Cheng FW, Leung TF, et al. Inflammatory cytokine profile in children with severe acute respiratory syndrome. Pediatrics 2004;113(1 Pt 1):e7-14. 